\title{
Devolved Healthcare: Is Kenya's Two-Tiered System of Government Hampering Response to COVID-19?
}

\author{
Ouma Atieno Sarah ${ }^{1}$, Rick Wolthusen ${ }^{2}$, Yasir Ahmed Mohammed Elhadi ${ }^{3 *}$, \\ Rose Sharon Ng'wono ${ }^{4}$, Marie Claire Wangari ${ }^{5}$, Theogene Uwizeyimana ${ }^{6}$, \\ Amos Abimbola Oladunni ${ }^{7}$, Salma Elmukashfi Eltahir Mohammed ${ }^{8}$, \\ Mashkur Abdulhamid Isa ${ }^{9}$ and Don Eliseo Lucero Prisno ${ }^{10}$ \\ ${ }^{1}$ Maseno University School of Medicine, Kenya

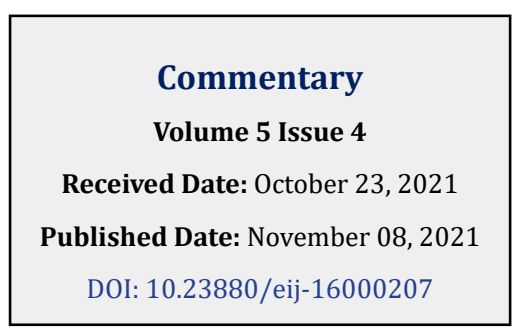

${ }^{2}$ Department of Psychiatry, Duke University Teaching Hospital

${ }^{3}$ Department of Public Health, Sudanese Medical Research Association, Sudan

${ }^{4}$ University of Eastern Africa Barton School of Public Health, Kenya

${ }^{5}$ Medical Doctor, Nazareth Hospital, Kenya

${ }^{6}$ Department of Public Health, Mount Kenya University Rwanda, Rwanda

${ }^{7}$ Faculty of Pharmaceutical Sciences, Ahmadu Bello University, Nigeria

${ }^{8}$ Department of Public Health and Caring Science, University of Uppsala, Sweden

${ }^{9}$ School of Health and Related Research, University of Sheffield, United Kingdom

${ }^{10}$ Department of Global Health and Development, London School of Hygiene and Tropical Medicine, United Kingdom

*Corresponding author: Yasir Ahmed Mohammed Elhadi, Department of Public Health, Medical Research Office, Sudanese Medical Research Association, Khartoum, Sudan, Email: Yasirelhadi25@gmail.com

\section{Abstract}

In 2013, Kenya transitioned into a two-tiered devolved system of government, comprising the national government and 47 semiautonomous county governments. Under devolution, all health service planning and delivery functions were transferred to county governments while the national government retained overall policy and regulatory functions. This division of roles was largely maintained in organizing and executing the COVID-19 response. As the pandemic spread, Kenya's policymakers faced the first significant challenge to the rather nascent devolved healthcare system-having to coordinate COVID-19 countermeasures between two tiers of government- the national and county governments. The COVID-19 pandemic presented a unique opportunity for an objective assessment of the performance of devolved healthcare. Nonetheless, unlike countermeasures by the national government which are widely documented, information and records on how the Kenyan counties and their governments dealt with COVID-19 is dearth. Given that they are fully in charge of healthcare delivery, there is a shortfall on clear overall objectives and strategy, general tactical actions, collectively, or as individual counties, which makes assessment difficult. Even in the face of this shortfall, certain instances of difficulty, political, legal, human resource and fiscal, stood out, that would clearly undermine the effort of the Kenyan counties/devolved healthcare. In the war against COVID-19. In peacetime, the health sector in nearly all counties was already laden with monumental challenges ranging from capacity gaps, human resource deficiency and dissatisfaction, lack of critical legal and institutional infrastructure, rampant corruption and a conflictual relationship with the national government. These challenges undermined the healthcare delivery function of the counties, and in a pandemic situation, crippled the efforts and abilities of the devolved units to respond to COVID-19 appropriately.

Keywords: Public Health; Health Administration; Kenya; COVID-19; Response Strategy 


\section{Epidemiology International Journal}

\section{Introduction}

In 2013, Kenya transitioned into a devolved system of governance comprising two levels; the national government and 47 semiautonomous county governments. Under devolution, the national government retained policy and regulatory functions while the health service delivery function was transferred to county governments. They were mandated with drafting county-specific integrated development plans; annual planning and budgeting; service delivery for public health, disease surveillance, community health services, primary health services, ambulance, county hospital services; recruitment and human resource management and partner coordination [1]. A detailed breakdown of the functions assigned to national and county governments is found in schedule 4 of the constitution [2]. On funding, the 47 devolved governments receive $15 \%$ of national revenue and allocate $5-7 \%$ of the total county budgets to health care. The proportion of total government budget (TGB) allocation to health at both national and county levels has ranged from $7.8 \%$ in $2012 / 2013$ to $9.2 \%$ in $2018 / 19$.

Evidence supports that there was an improvement in the structural health development with devolution of healthcare in Kenya [3]. However, the devolution of health services in Kenya has been characterized with challenges, so much so that there have seen several calls for the re-nationalization of healthcare services back to being a function of the national government [4]. The COVID-19 pandemic specifically shone a light on how the functional intricacies of Kenya's two-tiered government affected her response to the Coronavirus. These challenges, both pre-existing and new with the COVID-19 outbreak, include capacity gaps, human resource deficiency, fiscal delays, lack of critical legal and institutional infrastructure, rampant corruption and a conflictual relationship with the national government [5]. This paper aims to outline the efforts and unique challenges the devolved healthcare system faced in providing COVID-19 countermeasures in 2020, for a better understanding of how future responses can be bettered.

\section{Estimating County Level COVID-19 Activity, Risk, Capacity and Preparedness}

To provide context and to paint a clearer picture of countermeasures undertaken by the counties, they are listed in table 1.1 below, as provided by the Council of Governors $[6,7]$. For a better understanding of the different counties' levels of preparedness and capacity, worth noting are two indices by the Kenya Institute of Economic Affairs and the Urban Institute, which classified and rated all the 47 counties on two important indices, a healthcare capacity index and a population risk index (Figure 1) [8]. The two indices compared a county's healthcare capacity to respond to the Coronavirus vs the risk of its population contracting the disease and grouped the counties into four quadrants. The best-situated counties were the ones that scored highest in healthcare capacity and the lowest in population risk, the high capacity/low-risk quadrant. No county scored in this quadrant. Conversely, the counties that scored the lowest in capacity and highest in risk are the most vulnerable in relative terms low capacity/high-risk quadrant. This quadrant contained 7/47 counties-They were the counties least prepared for an upsurge of virus cases. Other factors also disadvantaged these counties, like their relatively large populations of close to or over 1 million [8].

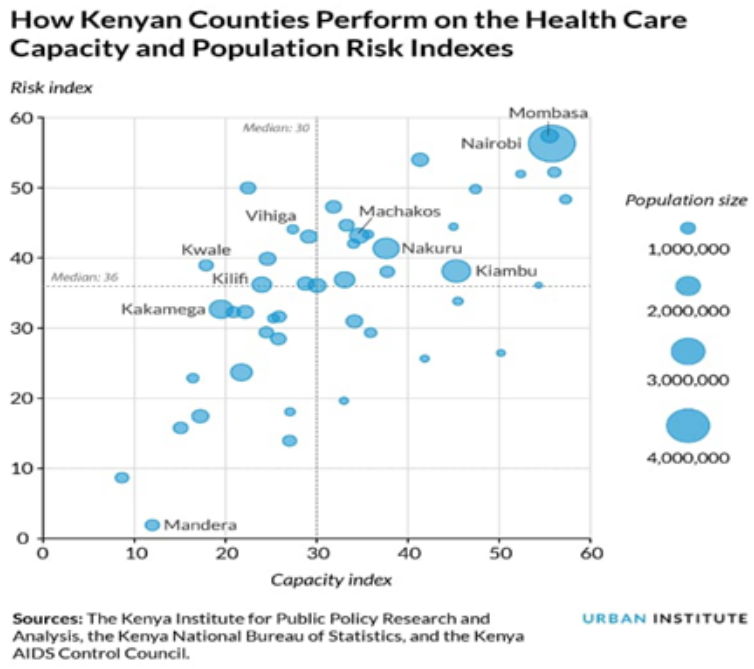

Figure 1: County capacity vs population risk index. 


\section{Epidemiology International Journal}

The low risk/low-capacity quadrant contains 16/47 counties several of which could be problematic, despite their low risk, because their population size could overwhelm their limited capacity [8]. The other quadrant was high risk and high capacity, containing 13/47 counties. However, even counties with high capacity were not secure as they may seem since a large population size meant that the existing healthcare capacity could have easily been overwhelmed with an upsurge of COVID-19 cases. These counties included Kenya's largest counties, Nairobi and Mombasa counties [8]. Even while most counties fell in categories where their populations were increasingly at risk of the Coronavirus and the counties themselves had low capacity to handle the outbreak, it is worth noting at this point, that there is an apparent shortfall in outlining a clear set of overall objectives and strategy, general tactical actions, and supporting information to enable an objective assessment of county COVID-19 management and while it can be argued that this would be overlapping with the functions of the national government, the counties are the implementers of national health policy and the providers of grassroots healthcare and are therefore best placed to monitor and report their specific data on COVID-19.

\begin{tabular}{|c|c|c|}
\hline Countermeasure & Date & Description \\
\hline ICU beds and ventilators & 1st April 2020 & $\begin{array}{l}\text { Only } 24 \text { counties had functional ICU facilities. } 22 \text { did not. Number of ICU } \\
\text { beds and ventilators totalled } 162 \text { and } 161 \text { respectively }\end{array}$ \\
\hline Human Resources for Health & & $\begin{array}{l}\text { National government was to support counties to hire an additional } \\
\qquad 6,656 \text { health workers. }\end{array}$ \\
\hline P.P.E & $20^{\text {th }}$ March 2020 & $\begin{array}{l}\text { KEMSA distributed } 694 \text { KN95 masks, } 32,000 \text { face masks, } 910 \text { medical } \\
\text { disposable overalls, } 735 \text { face shields, } 140 \text { pairs gumboots, } 2000 \text { N95 } \\
\text { masks. Only } 167 \text { sets of complete PPEs distributed }\end{array}$ \\
\hline Testing for COVID-19 & $1^{\text {st }}$ April 2020 & $\begin{array}{l}\text { Only two public labs- KEMRI and the National Influenza Laboratory had } \\
\text { capacity to test for COVID-19, limiting county testing capacity. Counties } \\
\text { to accredit private hospitals and laboratories to increase capacity. }\end{array}$ \\
\hline Isolation facilities & & $\begin{array}{l}\text { Governors identified and built capacity around isolation facilities in } \\
\text { their counties. }\end{array}$ \\
\hline Community sensitization & & $\begin{array}{l}\text { County governments were to facilitate community sensitization on } \\
\text { infection prevention in local vernacular stations and in sign language. }\end{array}$ \\
\hline Reduction of electricity tariffs & & $\begin{array}{l}\text { The Council of Governors requested the national government to lower } \\
\text { electricity tariffs for all medical facilities. }\end{array}$ \\
\hline $\begin{array}{c}\text { Waiver of CESS tax on } \\
\text { foodstuff and transportation }\end{array}$ & & $\begin{array}{l}\text { County Governments agreed waive CESS on food stuffs and } \\
\text { transportation of the same to ensure food security }\end{array}$ \\
\hline $\begin{array}{l}\text { Approval for County } \\
\text { Supplementary budget }\end{array}$ & & $\begin{array}{l}\text { Counties put in an emergency request for supplementary budget } \\
\text { to National Treasury for COVID-19 counter measures. } 7 \text { billion was } \\
\text { granted. }\end{array}$ \\
\hline Sanitizer supply & & $\begin{array}{l}\text { Following the agreement between the Council of Governors and Kenya } \\
\text { Pipeline Company Limited, for the supply of } 20,000 \text { litres of sanitizers } \\
\text { per week, sanitizer was to be supplied to counties, } 520 \text { litres per week } \\
\text { for counties with active cases, } 420 \text { litres per week for high-risk counties } \\
\text { and } 400 \text { litres per county per week. }\end{array}$ \\
\hline $\begin{array}{c}6^{\text {th }} \text { Virtual extraordinary } \\
\text { virtual session of national and } \\
\text { county governments summit }\end{array}$ & $10^{\text {th }}$ Nov. 2020 & $\begin{array}{l}\text { Consultative and coordination meeting that came up with the resolution } \\
\text { "no mask no service". }\end{array}$ \\
\hline Economic recovery plan & $31^{\text {st }}$ August 2020 & $\begin{array}{c}\text { Counties launched the COVID-19 Socio-economic Re-engineering } \\
\text { Recovery Strategy to be mainstreamed into county Integrated } \\
\text { Development Plans. }\end{array}$ \\
\hline Salary cuts & & $\begin{array}{c}\text { In line with the Presidential initiative to offer a voluntary reduction of } \\
\text { salaries of senior ranks of the National Executive, Governors and senior } \\
\text { county officials took a } 10-30 \% \text { pay cut. }\end{array}$ \\
\hline
\end{tabular}

Table 1: Outline of COVID-19 measures by Counties as listed by Council of Governors. 


\section{Epidemiology International Journal}

\section{Challenges}

\section{Human Resources for Health and Associated Shortages}

Kenya, like many other sub-Saharan countries, suffers from healthcare worker shortage. By 2015, Kenya had one doctor for ten thousand $(10,000)$ persons with one nurse per six hundred and fifty persons in Kenya against the WHO recommendation of one doctor for 1000 persons and one nurse per 280 persons [3]. This shortage couldn't be covered, even with county governments intending to recruit for an emergency an additional 6,656 HCWs [6] to cover the surge in the burden of disease due to COVID-19. Preexisting personnel challenges include long working hours, underpayment, late, irregular payment of salaries, and disparities in HCW remuneration across counties, causing HCW migration and concomitant inequitable distribution of health workers in the counties [3]. To these, COVID-19 added shortage of PPEs, fear and anxiety.

\section{Fiscal Delays}

According to the National Treasury, the national government has supported the financing of devolution. Since their establishment and as of the $2019 / 20$ financial year, the 47 Kenyan counties have received a cumulative 2.038 trillion KShs, in unconditional equitable revenue share, well above the $15 \%$ of gross national revenue, as stipulated by Article 219 of the Constitution [9]. Despite this, there has been conflicted between the county and national governments, on points of the amount shared in revenue allocation (counties have been asking for more than 15\%), as well as disagreements on the criteria for revenue allocation, which have caused stalemates delaying disbursements of funds. National Treasury lists that counties received an additional 7.7 Billion KShs specifically for the COVID-19 response [9]. However, over this COVID-19 period, counties have faced significant hurdles as regards finances and disbursement, so much so that at some time in the year, the Council of Governors had to declare a shutdown of counties due to lack of funds. The challenges included.

Revenue Allocation Bill stalemate: The County Revenue Allocation Bill which outlines the revenue division formula for counties was presented to the Senate on $14^{\text {th }}$ February but was argued and disagreed on in a stalemate that lasted until $6^{\text {th }}$ October 2020 , and finally gazetted on $12^{\text {th }}$ October 2020 [9]. Due to the stalemate, lack of a legal instrument to a direct transfer of funds disabled National Treasury from disbursing 316.5 billion KShs (2.88 billion USD) to counties, for the financial year 2020/21 [10]. Counties operated without this revenue for 3 months, occasioning the Council of Governors to call for a shutdown of all county services with the exception of few essential emergency services in hospitals.
Delayed Disbursement of Funds Due to Administrative Delays in the Counties: National Treasury notes that some counties failed to receive fund disbursements because they failed to meetrequirementsforspecific conditional allocations so that the exchequer could not distribute important vote heads like 338 million KeShs (3.08 Million USD) for the Transforming Health Systems Universal Healthcare Project [9]. More so, administrative-accounting delays in counties cost them another 14.7 billion KeShs (13 million USD) in conditional grants, effectively reducing the pool of funds counties could draw from to manage their healthcare services in the middle of the pandemic [9]. It can be seen how national politics and dysfunction in a national body, here the Senate, affects the functioning of the county governments. Even before COVID-19, delays in fiscal disbursements have been common, that counties see it as a political strategy by the national government to sabotage their health delivery so that citizens can push for the function to revert back to the national government $[1,11]$. In a pandemic situation, these delays not only undermined the objectives and spirit of devolution, and healthcare delivery but also the effort to countermeasure and manage the Coronavirus.

\section{Lack of Support for Devolved Healthcare by the Public, Political and Professional Stakeholders}

Since the inception of devolution, county governments have been in a prolonged fight for control of the healthcare system, with healthcare staff unions, the central government and members of the public who feel that healthcare should have never been devolved [4]. In 2013, healthcare was devolved before counties developed appropriate capacity and frameworks to handle major functions like HRH (Human Resources for Health) and EMMS (Essential Medicines and Medical Supplies). For HRH, this led to major disruptions in staff salary payments, political interference with $\mathrm{HRH}$ management functions and confusion over HRH management roles [3], occasioning rampant and drawn-out health worker strikes and mass resignations, witnessed even during the COVID-19 pandemic. Reviews in fact showed that devolution was associated with better attraction and retention of lower cadre staff, but the poor attraction of specialized health workers [3]. Severally clashing with county government, health-worker unions and the public have supported plans by both the legislature and the executive to have healthcare re-centralized and run by the national government [4]. As for the national government, it has a conflictual relationship with the devolved units, with accusations of deliberate sabotage $[3,4]$.

\section{Medical Supply Shortages}

Under devolution, county governments manage Essential Medicines and Medical Supplies (EMMS) for their 


\section{Epidemiology International Journal}

respective health facilities, sourcing for their pharmaceutical supplies solely from the Kenya Medical Supplies Authority (KEMSA). KEMSA is an autonomous authority independent from the national government but this seems to be only on paper. Government interference and influence remains too heavy for the authority to disentangle itself [12]. This has been the cause of constant tiffs between the counties and the national government. In April 2020, the authority was at the center of a spat between the Council of Governors and high-profile health officials of the national government, due to inefficient and price inflated delivery of COVID-19 supplies to the counties. This because the authority was compromised by logistical issues and mass graft implicating top national officials [13]. Consequently, county governors sought the liberty to source for medical supplies from other entities, going to the High Court to challenge Section 3 of the KEMSA Act which bars them from buying supplies from any entity other than KEMSA [4]. The continuous involvement of the national government and its officials in KEMSA, especially negatively (graft), endangers and undermines the autonomy and function of the counties in healthcare delivery [12], as demonstrated, most especially during this COVID-19 pandemic. With counties stating that they received insufficient supplies, frontline workers complaining of shortages and governors lobbying to be allowed to source for supplies elsewhere, it can be seen that a lack of medical supplies clearly undermined the COVID-19 response in the counties [13].

\section{Corruption}

During the COVID-19 pandemic, mass graft has been reported in Kenya, under the popular hashtag 'Covid Billionaires'. The Kenya Medical Supplies Authority was at the center of the scandal, awarding tenders worth billions to dubious companies [7]. The Council of Governors through its chair and frontline workers accused the authority of inefficiency, hyperinflation of prices of COVID-19 supplies, as well as delivery of substandard equipment. The delays due to corruption and logistical issues at KEMSA caused delays in medical supply refill rates at public health facilities in the counties, and occasioned shortages in reagents and drugs for COVID-19 testing, treatment and Intensive Care services, as well as shortages in PPEs for frontline healthcare workers $[13,14]$.

\section{Conclusion}

Prior to the COVID-19 pandemic, devolved healthcare faced number of challenges. They include capacity gaps, human resource deficiency, lack of critical legal and institutional infrastructure, rampant corruption and a conflictual relationship with the national government. The pandemic only magnified them. In a stress environment, the functional intricacies Kenya's two-tiered government system seemed to hamper a time-sensitive pandemic response, leaving Kenyans at risk.

\section{Recommendations}

The challenges experienced during this pandemic have the latent potential to be lessons and drivers of growth for the devolution agenda, and not just in the health sector. To meet the counties', need to deal with the Coronavirus pandemic, the national government and the counties will have to coordinate and work more closely with each other, to build capacity and trust around the devolved healthcare system, not just for the pandemic, but also for peacetime. The national government needs to further support the counties in building capacity, especially in dealing with Human Resources for Health and EMMS, for increased satisfaction and morale within the health taskforce. There needs to be an institutionalization of devolution and more political goodwill in supporting the functions of the county, and it should extend to fighting the graft that bedevils the healthcare system at both levels of government. As a foreseen, individual counties have varied risk and population variations. Counties and the devolved healthcare system in Kenya need to adopt a collective and individual performance accountability and reporting, especially for the COVID-19 countermeasures. This, to give room for county specific learning, objective assessment of performance, and for positive change and adaptation of responses. Even while recognizing that all the counties are different and unique, it would have been, still would be important that the counties band together to adopt a clear policy framework with a clear set of overall objectives and strategy, general tactical actions, and supporting information to enable successful measurement and reporting of COVID-19 management.

\section{References}

1. Kimathi L (2017) Challenges of the Devolved Health Sector in Kenya: Teething Problems or Systemic Contradictions?. Africa Development 42(1): 55-77.

2. Fourth Schedule. Distribution of functions between National and the county governments. Kenya Law Reform Commission (KLRC).

3. Tsofa B, Goodman C, Gilson L, Molyneux S (2017) Devolution and its effects on health workforce and commodities management-early implementation experiences in Kilifi County, Kenya. Int J Equity Health 16(1): 169.

4. (2020) Kenya's fight against COVID-19 with two-tiered governance system. The Africa Report. 


\section{Epidemiology International Journal}

5. Masaba BB, Moturi JK, Taiswa J, Mmusi Phetoe RM (2020) Devolution of healthcare system in Kenya: progress and challenges. Public Health 189: 135-140.

6. Centre M. Press Statement on Preparedness of Counties on COVID-19-1st April, 2020. Maarifa Centre.

7. (2020) Covid-19: Tracking Government Response in Kenya. Bowmans.

8. Galper H, Wamalwa N, Reehana R, Owino K, Mutua J (2020) COVID-19 in Kenya: Indices on County Healthcare Capacity and Populations at Risk. Africa Portal, pp: 1-45.

9. The National Treasury and Planning: Public statement on the status of payments to County Governments.

10. (2020) Republic of Kenya, the National Treasury and Planning: Press statement by the Cabinet Secretary National Treasury and Planning on disbursements of funds to county governments.

11. McCollum R, Limato R, Otiso L, Theobald S, Taegtmeyer M (2018) Health system governance following devolution: comparing experiences of decentralisation in Kenya and Indonesia. BMJ Global Health 3(5): e000939.

12. Fonshell J (2018) Corruption Devolved: People's Perceptions on Devolutions Impact on Transparency, Accountability and Service Delivery by the Government of Kisumu County, Kenya. Independent Study Project (ISP) Collection, pp: 1-34.

13. (2020) Coronavirus corruption in Kenya: Officials and businesspeople targeted. BBC News.

14. (2020) Counties row with drugs agency bad for Covid-19 fight. The Standard. 